\title{
Leukaemia inhibitory factor in endometrium during the oestrous cycle, early pregnancy and in ovariectomized steroid-treated ewes
}

\author{
D. Vogiagis ${ }^{1}$, R. C. Fry ${ }^{2}$, R. M. Sandeman ${ }^{3}$ and L. A. Salamonsen ${ }^{1 *}$ \\ ${ }^{1}$ Prince Henry's Institute of Medical Research, Clayton, 3168; ${ }^{2}$ Victorian Institute of Animal Science, \\ Werribee, 3030; and ${ }^{3}$ La Trobe University Bundoora, 3083, Victoria, Australia
}

\begin{abstract}
Leukaemia inhibitory factor (LIF), a pleiotropic cytokine, is essential for blastocyst implantation in mice and maintains the development of ovine embryos in culture. The expression of LIF was examined by northern blot analysis in endometrial tissue from cyclic (days 4-16) and pregnant (days 4-20) ewes, and the corresponding protein was immunolocalized. Expression of mRNA encoding LIF remained relatively constant throughout the oestrous cycle and was present during early pregnancy. A decrease in mRNA encoding LIF was observed during early pregnancy (on days 12-14) and expression was highest on days 16-20. Immunoreactive LIF was present in the cellular compartments of the endometrium throughout the oestrous cycle and early pregnancy, with maximal immunostaining in the caruncular and intercaruncular luminal epithelium, and moderate staining in the glandular epithelium and intercaruncular stroma. Immunoreactive LIF was also detected in the trophoblast cells of day 17 blastocysts. Separately cultured endometrial epithelial and stromal cells from pregnant animals both expressed mRNA encoding LIF. Ovariectomized steroid-treated ewes were studied to establish whether steroid hormones had a role in regulating endometrial LIF. Ewes treated with oestradiol alone showed lower concentrations of immunoreactive LIF in the endometrium in comparison to ovariectomized, control animals, while treatment of ovariectomized animals with both oestradiol and progesterone had a greater inhibitory effect on LIF immunolocalization. These studies demonstrate the presence of mRNA encoding LIF and protein throughout the oestrous cycle and early pregnancy and suggest that steroid hormones may be involved in their regulation.
\end{abstract}

\section{Introduction}

Leukaemia inhibitory factor (LIF) is a cytokine that has a history of discovery and rediscovery owing to its range of pleiotropic actions on many different cells (reviewed in Gough et al., 1992); the name under which the cDNA and genomic clones were originally isolated is the one most commonly used (Gearing et al., 1987, 1988). It was identified initially by its ability to induce macrophage differentiation in the myeloid leukaemic cell line M1 (Tomida et al., 1984; Gearing et al., 1987; Hilton et al., 1988) and was shown subsequently to inhibit the differentiation of cultured embryonic stem cells, maintaining their ability to contribute to the germline of chimaeric mice (Smith et al., 1988; Williams et al., 1988). Recombinant human LIF also maintains the development of ovine embryos in culture (Fry et al., 1992), while mouse blastocysts cultured in the presence of LIF have a greater mass of trophectoderm in comparison with control blastocysts, suggesting that the trophectoderm is a site of action (Robertson et al., 1991). Furthermore, LIF significantly increases the number of mouse embryos hatching and exhibiting trophoblast outgrowth

*Correspondence.

Received 29 May 1996.
(Lavranos et al., 1995). Therefore, it may play a role in regulating the growth and development of early embryos.

In the mouse uterus, LIF is expressed in the endometrial glands coincident with the time of blastocyst implantation and occurs possibly as a direct response to the increase in circulating oestrogen on day 3 and day 4 of pregnancy (Bhatt et al., 1991). Endometrial LIF appears to be essential for blastocyst implantation in mice; mice that lack a functional LIF gene have normal blastocysts that fail to implant (Stewart et al., 1992). The low affinity LIF receptor (LIFR) is an integral component of the functional LIF receptor complex and interacts with the component, gp130, to form a high-affinity receptor (Gearing et al., 1992; Ip et al., 1992; Taga and Kishimoto, 1992; Davis et al., 1993). Targeted mutation of LIFR (Ware et al.. 1995) and gp130 (Yoshida et al., 1996) have both been demonstrated. Disruption of LIFR leads to perinatal death as mouse embryos homozygous for the mutation (LIFR $-l-$ ) die shortly before or during birth owing to a range of defects (Ware et al., 1995), while embryos homozygous for the gp130 mutation (gp130 $-(-)$ die progressively between 12.5 days postcoitum and term (Yoshida et al., 1996). In both cases, normal implantation of embryos occurs, suggesting that endometrial LIF may not act directly through LIFR or gp130 on the blastocyst (Ware et al., 
1995; Yoshida et al., 1996) and, since both mutations are lethal, their effects in adult mice cannot be investigated

In human endometrium mRNA encoding LIF is present transiently, and the highest expression observed during the mid- and late secretory phases of the menstrual cycle (Charnock-Jones et al., 1994; Kojima et al., 1994; Arici et al., 1995; Vogiagis et al., 1996). Furthermore, immunoreactive LIF was localized maximally in the endometrial epithelium during the mid- and late secretory phases, while moderate immunostaining was observed in the stroma throughout the menstrual cycle (Vogiagis et al., 1996). Therefore, LIF may have an effect on endometrial function. Given that human implantation commences in the mid-secretory phase, LIF may be implicated in embryo implantation, although endometrial LIF from early human pregnancy has not been investigated. Sheep, unlike humans and mice, have a characteristically long period of intrauterine blastocyst development before implantation (Bindon, 1971). In mice, the blastocyst hatches from the zona pellucida and implants on the uterine wall on day 4 of pregnancy (Finn and McLaren, 1967; Orsini and McLaren, 1967); in sheep, hatching and implantation occur about 8 days apart (Rowson and Morr, 1966; Bindon, 1971), thus allowing the opportunity to study the role of endometrial LIF during preimplantation growth, development and subsequent implantation. In this study we investigated the endometrial expression and localization of LIF throughout the oestrous cycle and early pregnancy in ewes. The expression and localization of LIF in the ovine endometrium was demonstrated, and both endometrial stromal and epithelial cells were found to have the capacity to produce mRNA encoding LIF in vitro. Furthermore, LIF was localized on day 17 blastocysts and the regulation of LIF by ovarian steroids was investigated.

\section{Materials and Methods}

\section{Animals}

All animal experimentation was approved by the animal ethics committees at the Victorian Institute of Animal Science, Werribee and at the Monash Medical Centre, Clayton.

Parous Corriedale ewes $(n=62)$ were run with either vasectomized or intact rams fitted with marking harnesses for detection of behavioural oestrus (day $=0)$. Ewes were taken to surgery on days $4,10,12,14$ and $16\left(n=4\right.$ day $\left.^{-1}\right)$ of the cycle, or days $4,7,8,9,10,12,14,15,16,17$ and $20(n=3-4$ day $^{-1}$ ) of pregnancy (total $n=42$ ). On the day before surgery, animals were penned and food and water were withheld. Ewes were anaesthetized with sodium thiopentone and maintained with halothane. The uterus was exteriorized by mid-ventral laparotomy. Uteri were flushed with $20 \mathrm{ml}$ saline and pregnancy was confirmed by the presence of a conceptus. Ewes were hysterectomized and wedges of endometrium plus myometrium along with day 17 blastocysts were collected and fixed immediately. Endometrial tissues were dissected from myometrium and snap frozen in liquid nitrogen.

\section{Steroid-treated ewes}

Parous Corriedale ewes $(n=16)$ were ovariectomized at least 4 weeks before the treatment. Animals were allocated to four groups ( $n=4$ per group), each of similar mean live mass, and treated as follows: group 1: ovariectomized (no treatment); group 2: oestrogen alone: group 3: progesterone alone; group 4: oestrogen plus progesterone. Oestrogen treatments were by Silastic implants as described by Salamonsen et al. (1985) and progesterone was administered intravaginally using EAZIbreed CIDR G (Riverina Artificial Breeders Pty Ltd, Albury, NSW). These implants were designed to produce peripheral concentrations of oestradiol and progesterone similar to those seen during the normal cycle (Salamonsen et al., 1991). The ewes were hysterectomized on day 12 and uterine tissue fixed immediately for use in immunohistochemistry.

\section{Northern blot analysis}

Total RNA was isolated from individual samples of endometrial tissue (Chomczynski and Sacchi, 1987) and $20 \mathrm{mg}$ samples subjected to electrophoresis in a $1.2 \%$ agarose gel and transferred to Hybond nylon membranes (Amersham International, Sydney) by northern blotting. Membranes were prehybridized for $4 \mathrm{~h}$ in hybridization buffer $(50 \%$ formamide, I-strength Denhardt's solution (50-strength is $1 \%(\mathrm{w} / \mathrm{v})$ each of Ficol, polyvinylpyrrolidone and BSA), 5-strength SSPE $\left(0.75 \mathrm{~mol} \mathrm{NaCl} \mathrm{l}^{-1}, 50 \mathrm{mmol} \mathrm{NaH} \mathrm{PO}_{4} \cdot 2 \mathrm{H}_{2} \mathrm{O} \mathrm{I}^{-1}, 5 \mathrm{mmol}\right.$

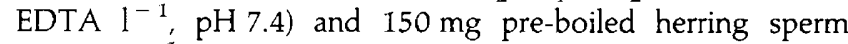
DNA $\mathrm{ml}^{-1}$ ) at $42^{\circ} \mathrm{C}$ and hybridized with randomly primed ${ }^{32}$ P-labelled LIF $\left(2 \times 10^{6}\right.$ c.p.m. $\left.\mathrm{ml}^{-1}\right)$ in the same buffer for $16-18 \mathrm{~h}$ at $42^{\circ} \mathrm{C}$. The probe used in this study was a $\sim 0.6 \mathrm{~kb}$ ovine LIF cDNA fragment containing the mature coding region of LIF (a generous gift from T.A. Willson, The Walter and Elisa Hall Institute, Melbourne). All blots containing samples for comparison (pregnant, cyclic) were hybridized in one batch with the same labelled probe. Filters were washed with $2 \times \mathrm{SSC}, 0.1 \%(\mathrm{w} / \mathrm{v}) \mathrm{SDS}$ at $42^{\circ} \mathrm{C}$ and finally in $1 \times \mathrm{SSC}, 0.1 \%$ $(w / v)$ SDS at $60^{\circ} \mathrm{C}$. Subsequently, filters were washed and rehybridized with a $18 \mathrm{~S}$ oligonucleotide probe (a gift from P. Fuller, Prince Henry's Institute of Medical Research, Melbourne; $2 \times 10^{6}$ c.p.m. $\mathrm{ml}^{-1}$ ) and washed with a final concentration of $1 \times \mathrm{SSC}, 0.1 \%(\mathrm{w} / \mathrm{v}) \mathrm{SDS}$ at $60^{\circ} \mathrm{C}$. Autoradiography was performed with FujiRX film and densitometric analysis was with an Olympus Cue 2 image analyser. Relative concentrations of mRNA encoding LIF were corrected for loading according to the relative signals for $18 \mathrm{~S}$.

\section{Immunohistochemistry}

A polyclonal antiserum raised in a rabbit against the human LIF protein (AMRAD Pharmacia Biotech, Boronia, Victoria) was used to detect immunoreactive LIF in tissue sections. The specificity of this antibody has been previously assessed by western blot, against mouse and human recombinant nonglycosylated LIF, human recombinant glycosylated LIF and human endometrial extract (Vogiagis et al., 1996). Furthermore, human LIF has biological activity on ovine embryos (Fry et al, 1992), and human and ovine LIF have $88 \%$ sequence identity of amino acid sequences (Willson et al., 1992). Fixed ovine uterine tissues were randomized for processing in batches with a section from a standard day 16 sample included in each batch as a positive control and for confirmation of reproducibility 
between batches. Endogenous peroxidases were quenched from tissue sections with $3 \%(\mathrm{v} / \mathrm{v}) \mathrm{H}_{2} \mathrm{O}_{2}$ in methanol for $5 \mathrm{~min}$, then the sections were washed and blocked with $10 \%(\mathrm{v} / \mathrm{v})$ normal goat serum (NGS) in Tris-buffered saline (TBS). On each slide one section was exposed to primary antiserum and one to normal rabbit serum (NRS) each at 1:3000 in TBS, and left overnight at $4^{\circ} \mathrm{C}$. Sections were washed in TBS for $10 \mathrm{~min}$ and incubated for $1 \mathrm{~h}$ with Vector $A B C$ reagents prepared according to manufacturer's instructions (Vector Laboratories Burlinghame, CA). Sections were washed further with TBS for $10 \mathrm{~min}$ before being developed with a peroxidase substrate ( $\mathrm{I} \mathrm{mg} \mathrm{diaminobenzidine} \mathrm{tetrahydrochloride} \mathrm{ml}^{-1}$ (Sigma) and $\left.3.3 \%(\mathrm{v} / \mathrm{v}) \mathrm{H}_{2} \mathrm{O}_{2}\right)$, counterstained with $\mathrm{I}: 10$ Harris haematoxylin (Sigma) to establish morphology, then rehydrated and mounted. Stained sections were examined by two observers and individual cellular components within each tissue were scored from 0 (negative) to 4 (maximal staining intensity). Results were expressed as mean staining intensity \pm SEM. The SEM was shown to illustrate the variability between individual animals.

\section{Preparation and culture of endometrial cells}

Uteri from two parous Corriedale ewes were collected at an abattoir; both had fresh corpora lutea of healthy appearance on their ovaries. A mixture of stromal fibroblasts and epithelial cells was prepared from the endometrium (as described by Salamonsen et al., 1985). Briefly, tissue was chopped finely with scissors and digested with bacterial collagenase in a shaking water bath for $75 \mathrm{~min}$. Cells were filtered through two grades of nylon mesh $(80 \mu \mathrm{m})$. This filter was backwashed and the harvested glands were washed in culture medium. Pooled glands from the two animals were seeded in $75 \mathrm{~mm}$ flasks in Dulbecco's minimum essential medium (DMEM; Trace Biosciences, Sydney) with $10 \%(\mathrm{v} / \mathrm{v})$ fetal calf serum (FCS) and penicillin-streptomycin-fungizone (both from Flow Laboratories, Sydney). The single-cell suspensions (primarily stromal cells) were also pooled and washed. Approximately $1.5 \times 10^{7}$ cells were added to the same medium in $75 \mathrm{~mm}$ flasks. After $48 \mathrm{~h}$, cells were confluent and the medium was changed. After a further $48 \mathrm{~h}$, cells were washed twice with PBS (Trace Biosciences) and harvested by scraping, with a rubber policeman, into buffer for RNA extraction. Identification of cell types (epithelial and stromal) was by their characteristic appearance under phase-contrast microscopy and by immunostaining for cytokeratin and fibronectin, respectively (Cherny and Findlay, 1990).

\section{Statistical analysis}

Results from densitometric analysis of northern blots were analysed using the Mann-Whitney $U$ test. A probability of $P<0.05$ was regarded as significant.

\section{Results}

\section{Northern blot analysis}

Total RNA was isolated from ovine endometrial tissues throughout the oestrous cycle and early pregnancy and was (a)

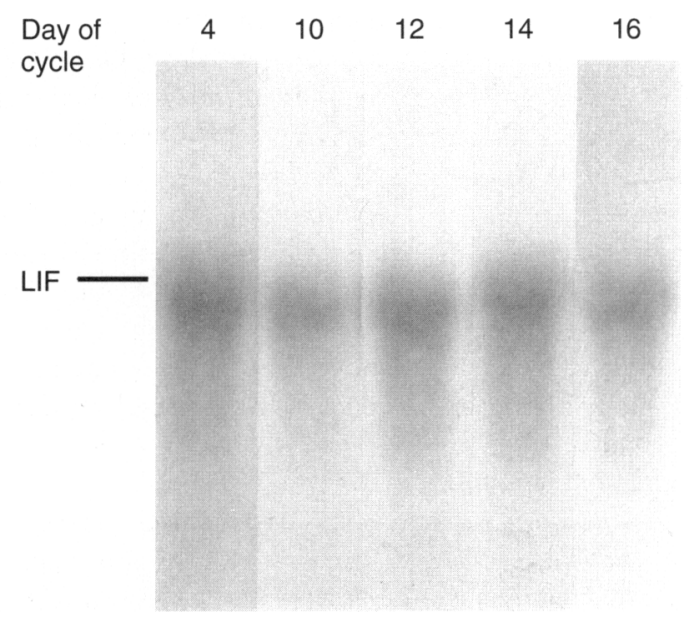

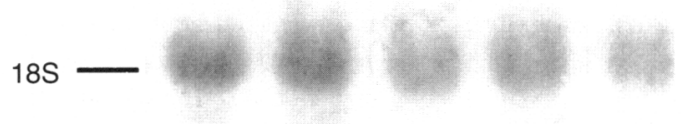

(b)

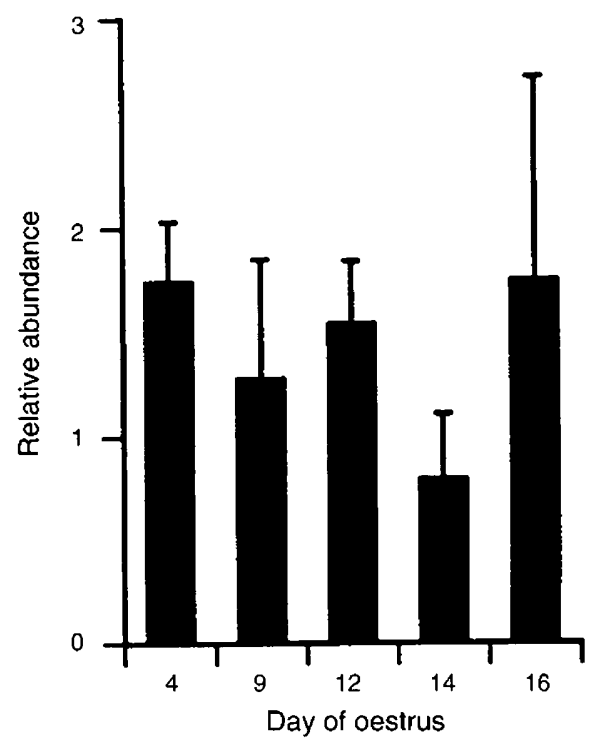

Fig. 1. (a) Northern blot analysis of total RNA ( $20 \mu \mathrm{g}$ per lane) from individual samples of ovine endometrium during the oestrous cycle. The blots were hybridized sequentially with ${ }^{32} \mathrm{P}$-labelled probes for leukaemia inhibitory factor (LIF) $(4.2 \mathrm{~kb})$ and $18 \mathrm{~S}(1.8 \mathrm{~kb})$. (b) Relative mRNA concentrations after correction for loading according to the relative signal for $18 \mathrm{~S}$ using densitometric analysis.

examined by northern blot analysis. The $\sim 4.2 \mathrm{~kb}$ mRNA transcript encoding LIF (Figs 1 and 2 ) is expressed throughout both early pregnancy and the oestrous cycle. The relative mRNA concentrations corrected for loading relative to the signal for $18 \mathrm{~S}$ rRNA (performed by densitometric analysis) are also shown in each figure. There appears to be some variability in transcript concentrations throughout both the oestrous cycle 
(a)

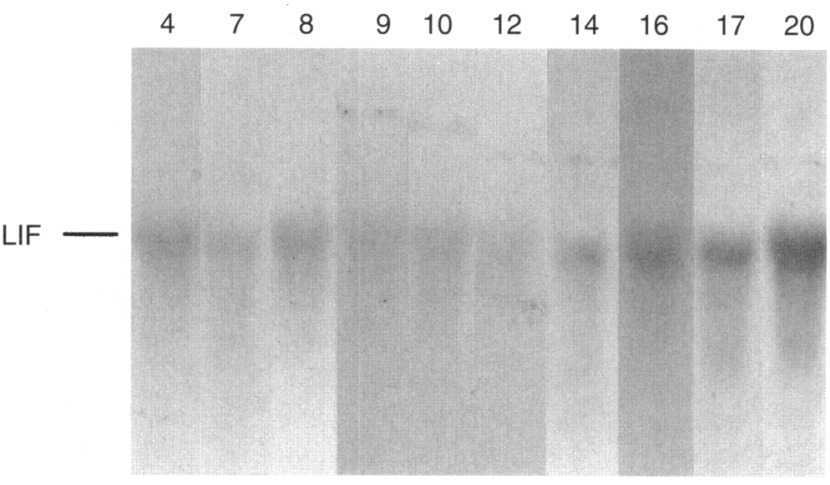

$18 \mathrm{~S}$

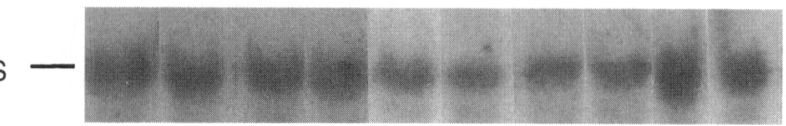

(b)

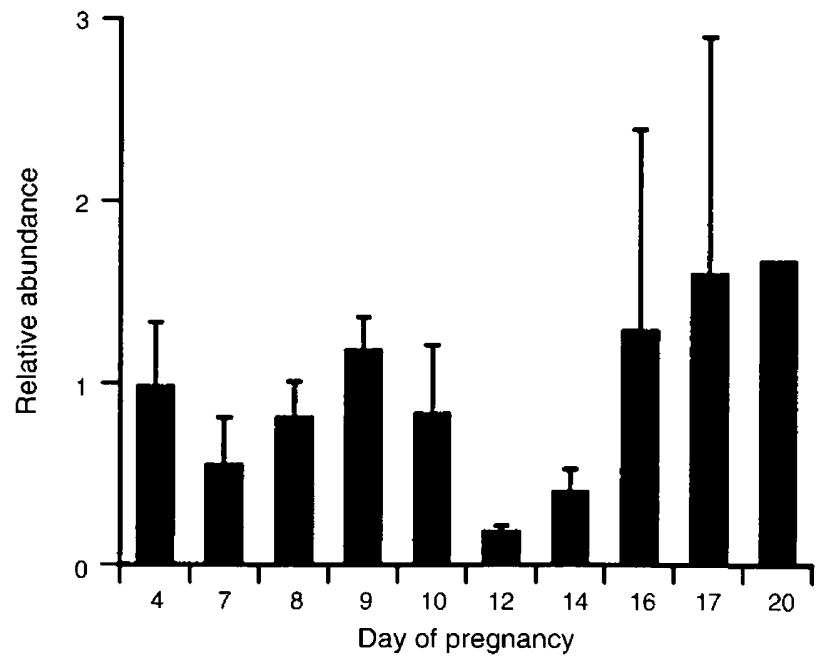

Fig. 2. (a) Northern blot analysis of total RNA ( $20 \mu \mathrm{g}$ per lane) from individual samples of ovine endometrium during early pregnancy, days $4-20$. The blots were hybridized sequentially with ${ }^{32} \mathrm{P}$-labelled probes for leukaemia inhibitory factor (LIF) $(4.2 \mathrm{~kb})$ and $18 \mathrm{~S}(1.8 \mathrm{~kb})$. (b) Relative mRNA concentrations after correction for loading according to the relative signal for $18 \mathrm{~S}$ using densitometric analysis.

(Fig.1) and early pregnancy (Fig. 2); statistical analysis of the data showed no significant differences with either group, probably owing to the large variability in mRNA expression among individual animals on the same day.

Purified ovine endometrial stromal and epithelial cells, cultured in the presence of $10 \% \mathrm{FCS}$ for $48 \mathrm{~h}$ were both shown to express the $\sim 4.2 \mathrm{~kb}$ mRNA transcript encoding LIF (Fig. 3).

\section{Immunohistochemistry}

Oestrous cycle. The relative intensities of LIF immunostaining in individual cellular compartments of the endometrium and at different days of the oestrous cycle are summarized (Fig. 4). In the glandular epithelium, moderate LIF immunostaining was found throughout the oestrous cycle in (a) (b)

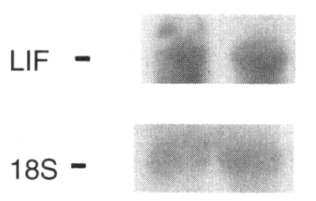

Fig. 3. Northern blot analysis of total RNA ( $20 \mu \mathrm{g}$ per lane) from purified ovine endometrial (a) epithelial and (b) stromal cells, cultured for $48 \mathrm{~h}$ in medium containing $10 \%(\mathrm{v} / \mathrm{v})$ fetal calf serum. The blot was hybridized sequentially with ${ }^{32} \mathrm{P}$-labelled probes for leukaemia inhibitory factor (LIF) $(4.2 \mathrm{~kb})$ and $18 \mathrm{~S}$ (1.8 kb).

the intercaruncular endometrium, and lower concentrations of immunoreactive LIF were present in the deep glands. Immunoreactive LIF was present maximally in the intercaruncular and caruncular regions of the luminal epithelium, and a slight increase in intensity of staining occurred towards the end of the oestrous cycle. In the intercaruncular stroma, LIF immunoreactivity was high only during days 10-14 of the cycle, while the lowest LIF immunoreactivity was observed in the caruncular stroma throughout the cycle. In each of the cellular compartments the lowest intensity of staining for immunoreactive LIF appeared on day 4 .

Early pregnancy and day 17 trophoblast. The relative intensities of LIF immunostaining in individual cellular compartments of the endometrium and at different days of early pregnancy are summarized (Fig. 5) and representative photomicrographs are shown (Fig. 6a-d). Photomicrographs of immunoreactive LIF on day 17 trophoblast are also shown (Fig. 6e). The pattern of LIF immunostaining during early pregnancy was similar to that observed during the oestrous cycle; the greatest intensity occurred in the caruncular and intercaruncular regions of the luminal epithelium, and moderate LIF immunostaining was present in the glandular epithelium (Fig. 5). The lowest LIF immunoreactivity in epithelium was observed in the deep glands throughout early pregnancy. Overall, the lowest LIF immunoreactivity in any compartment was seen in the caruncular stroma. The intercaruncular stroma showed the largest variation of immunoreactive LIF throughout the cycle, reaching a peak on day 12 (Fig. 6b) with lower concentrations observed on days 4 and 20 (Fig. 6a, c), while immunostaining in the glandular epithelium appeared moderate and relatively constant (Fig. 6a-c). Strong immunostaining was present on day 20 in the intercaruncular luminal epithelium (Fig. 6c). Staining was absent in sections treated with NRS at the same dilution as the anti-LIF serum (Fig. 6d). In most compartments, the greatest amount of immunoreactive LIF was observed after day 10 of early pregnancy (Fig. 5). Immunoreactive LIF was localized on day 17 of the trophoblast (Fig. 6e) and was absent in a section in which anti-LIF was replaced with NRS at the same dilution (Fig. 6f).

Steroid treatment. The relative intensities of LIF immunostaining in individual cellular compartments in the endometrium of ovariectomized and steroid-treated ewes are summarized (Fig. 7). Positive immunostaining for LIF was observed in all compartments and in all tissues except in the deep glands and caruncular stroma of oestradiol plus 
(a)

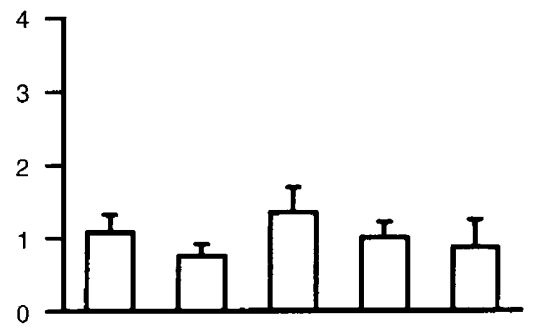

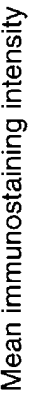

(c)

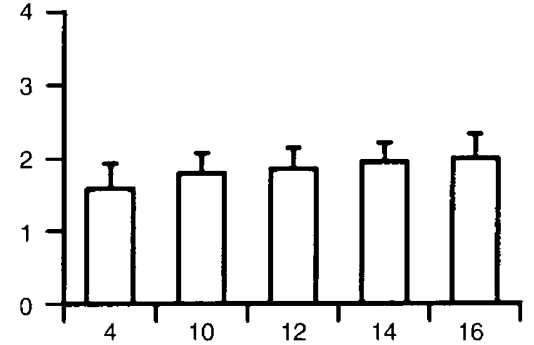

(d)

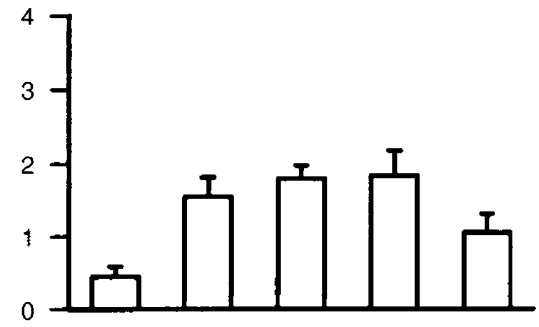

(e)

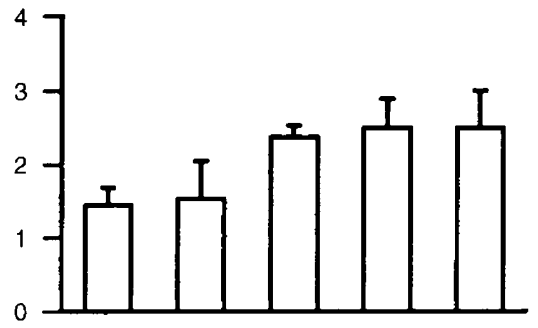

(f)

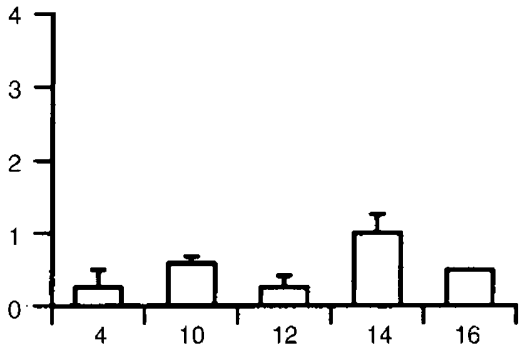

Day of cycle

Fig. 4. Distribution and relative intensity of positive immunoreactivity for leukaemia inhibitory factor (LIF) in ovine endometrial tissue during the oestrous cycle, days 4-16. (a) Intercaruncular deep glands; (b) luminal epithelium; (c) glandular epithelium; (d) stroma; (e) caruncular luminal epithelium; and (f) caruncular stroma.

progesterone-treated ewes. In comparison with untreated ovariectomized control ewes, treatment with oestradiol slightly decreased or maintained LIF immunostaining in most cellular compartments. Treatment with progesterone alone resulted in a decrease in LIF immunoreactivity in the luminal epithelium and an increase in immunoreactive LIF in the glandular epithelium and stroma, while immunostaining was maintained in the caruncular stroma compared with that in ovariectomized ewes. Combined treatment with oestradiol and progesterone resulted in a decrease in the intensity of LIF immunoreactivity in all tissues, including stroma, glandular and luminal epithelium when compared with ovariectomized ewes or the majority of other treatment groups.

\section{Discussion}

In this study the expression of the mRNA transcript encoding LIF, and LIF protein in ovine endometrium was examined throughout the oestrous cycle and early pregnancy. Ovarian steroids were shown to be involved in the regulation of changes in LIF production throughout the uterus using ovariectomized, steroid-treated ewes. Furthermore, immunoreactive LIF was demonstrated on day 17 trophoblasts.

Immunoreactive LIF was found in most cellular compartments of the ovine endometrium throughout the oestrous cycle and early pregnancy, and appeared to increase after day 10 . The LIF transcript was also present throughout the oestrous cycie and early pregnancy, without significant changes. These results suggest that uterine LIF may be maternally regulated and is not related to the presence of a blastocyst in the uterine lumen. Similarly, in human and rabbit endometrium, mRNA encoding LIF is expressed and translated during the menstrual or oestrous cycle (Charnock-Jones et al., 1994; Kojima et al., 1994; Yang et al., 1994; Arici et al., 1995; Yang et al., 1995; Cullinan et al., 1996; Vogiagis et al., 1996) and in mouse endometrium, pseudopregnant females also express mRNA encoding LIF on the day 4 of pregnancy (Bhatt et al., 1991).

The most striking difference between this study in sheep and that of the previous work in mice is that the LIF transcript and 


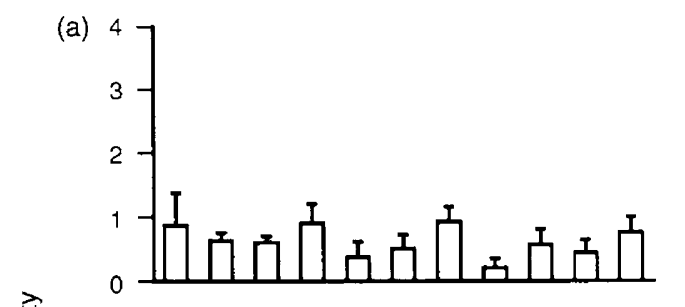

(d)
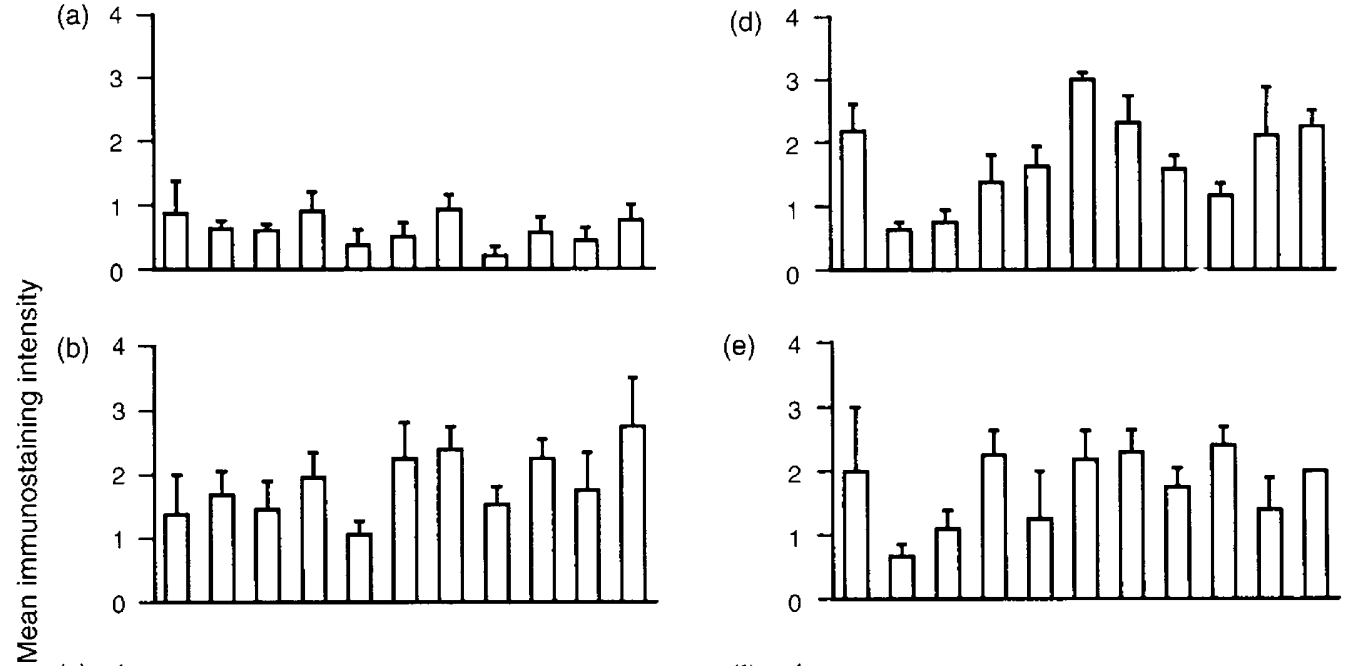

(e)

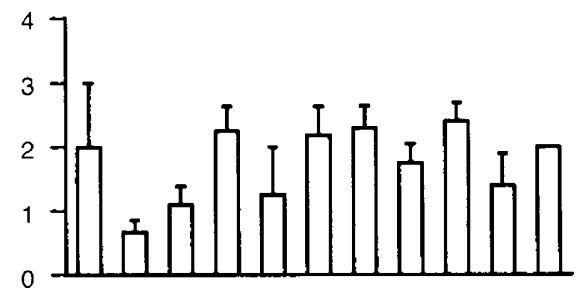

(c)

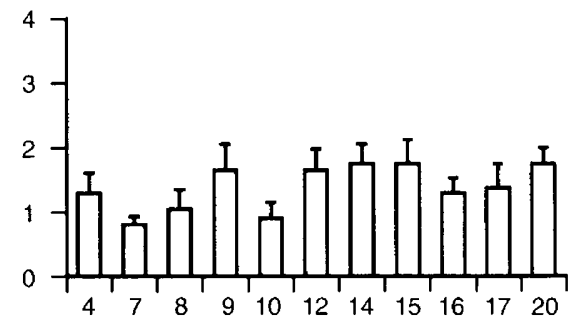

(f)

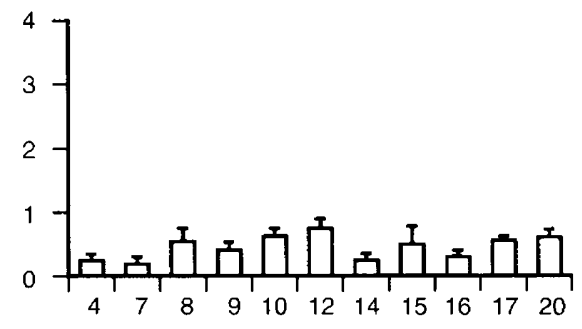

\section{Day of pregnancy}

Fig. 5. Distribution and relative intensity of positive immunoreactivity for leukaemia inhibitory factor (LIF) in ovine endometrial tissue during early pregnancy, days 4-20. (a) Deep glands, intercaruncular; (b) luminal epithelium; (c) glandular epithelium; (d) stroma; (e) caruncular luminal epithelium; and (f) caruncular stroma.

protein in ovine endometrium are not confined predominantly to the day of implantation (Bhatt et al., 1991). Their presence in endometrial epithelium suggests that LIF may be secreted into the uterine lumen and be involved in the processes spanning days $4-20$ of early pregnancy, including the growth, development and implantation of the ovine blastocyst. Previous studies have demonstrated that culture in media containing rhLIF of both mouse and ovine embryos results in increased proportions of blastocysts or embryos hatching from the zona pellucida (Fry et al., 1992; Lavranos et al., 1995). In this study, an increase in immunoreactive LIF at the time of blastocyst hatching (day 9 of pregnancy), particularly in the luminal epithelium (caruncular and intercaruncular) and glandular epithelium, was observed and the LIF transcript was also present in the endometrium. These data support the possibility of a role for LIF in blastocyst hatching.

- Since the sheep trophoblast undergoes a phase of rapid preimplantation growth between day 12 and day 16 of pregnancy (Rowson and Moor, 1966; Bindon 1971) and LIF is known to have mitogenic actions on a number of cell types including embryonic stem cells (Williams et al., 1988), LIF may be involved in this rapid growth and development of the ovine blastocyst before implantation. LIF may also have a mitogenic effect in the endometrium; addition of LIF to cultured ovine stromal cells had a dose-response effect on their proliferation (Salamonsen et al., 1997). The demonstration that immunoreactive LIF increased from day 10 of pregnancy to the day of embryo implantation (day 16) supports the hypothesis of a mitogenic role for LIF on the blastocyst or endometrium, or on both. Alternatively, LIF may act as a ligand involved in preparation of the blastocyst for attachment to the luminal surface. LIF may also act in an autocrine manner and bind to receptors of the caruncular epithelium to make this region favourable for attachment of the trophoblast.

In sheep, trophoblast invasion is limited to breaching of the subepithelial basal lamina and minor incursions of trophoblast into the underlying stroma, but during placentome formation there is extensive and rapid tissue remodelling (Boshier, 1969; Reynolds and Redmer, 1992; Wooding and Flint, 1994). In cultured peri-implantation mouse blastocysts (Harvey et al., 1995), LIF regulates two members of the proteinase family, uPA and MMP-9, involved in the degradation of the extracellular matrix associated with tissue remodelling (Woessner, 1991; Birkedal-Hansen et al., 1993). Harvey et al. (1995) suggest that uterine-derived LIF is required to stimulate embryonic uPA and MMP-9 activity to allow implantation and further placentation. LIF has previously been implicated in human (Gearing et al., 1991) and mouse (Ware et al., 1995) placentation. It is important to note that implantation and placentation in these species differs from that in sheep, which have a much less invasive form of implantation that results in the formation of a synepitheliochorial placenta (reviewed in Wooding and Flint, 1994), although the ovine trophoblast does produce MMP-9 (Salamonsen et al., 1995). The presence of LIF in ovine endometrium at the time when placental development is initiated (days 17-20) suggests that LIF has a role in placentation in sheep. In this study, high concentrations of LIF transcript and protein were present at the time of placentation 

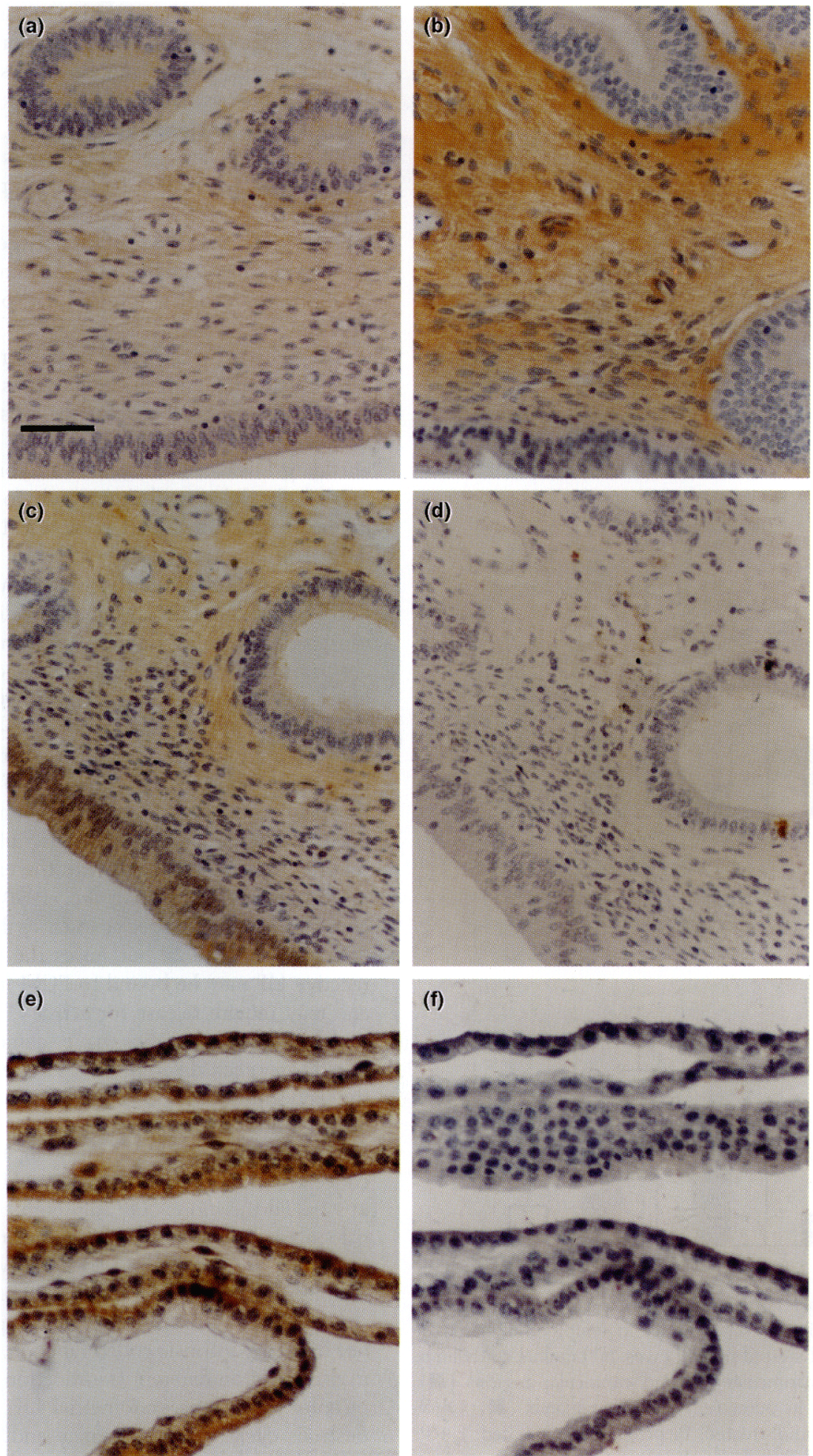

Fig. 6. Immunohistochemical localization of leukaemia inhibitory factor (LIF) in ovine endometrium during early pregnancy and on day 17 ovine trophoblast. All sections were counterstained with haematoxylin. Intercaruncular tissue showing stroma, glandular and luminal epithelium on: (a) day 4; (b) day 12; (c) day 20; and (d) the same tissue as that used in (c), exposed to normal rabbit serum in place of LIF antiserum. Localization on day 17 ovine trophoblast: (e) immunoreactive LIF; ( $f$ ) the same tissue exposed to normal rabbit serum instead of LIF antiserum. Scale bar represents $100 \mu \mathrm{m}$. 
(a)
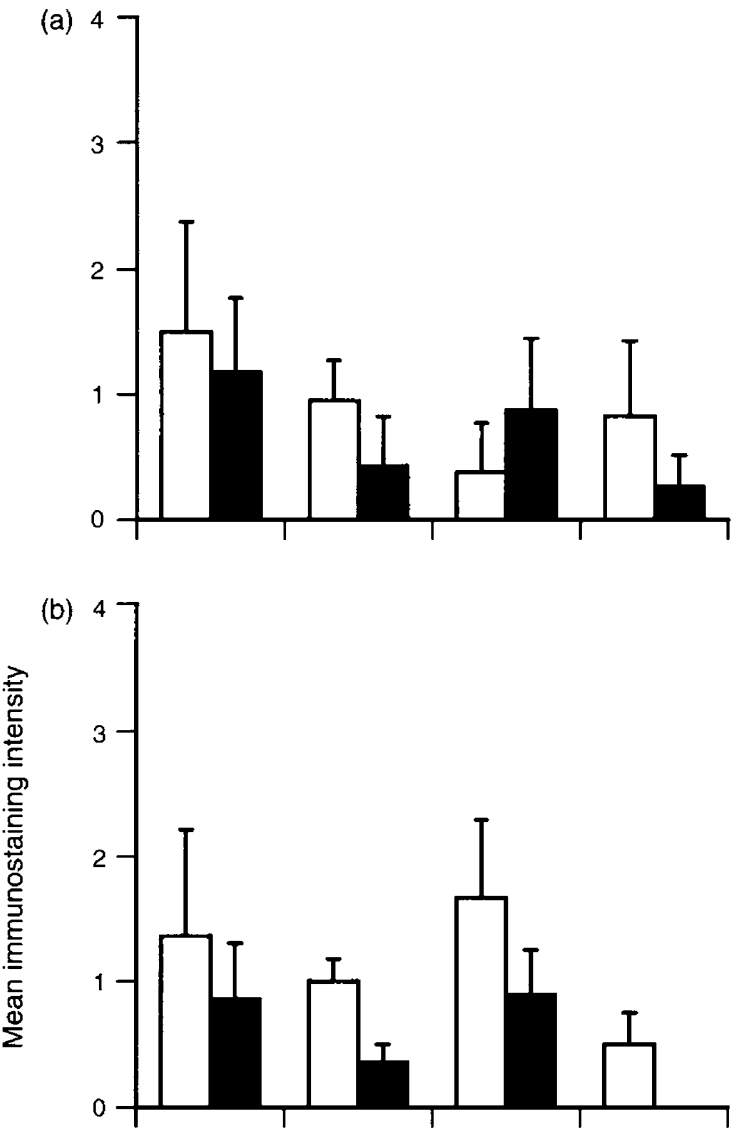

(c)

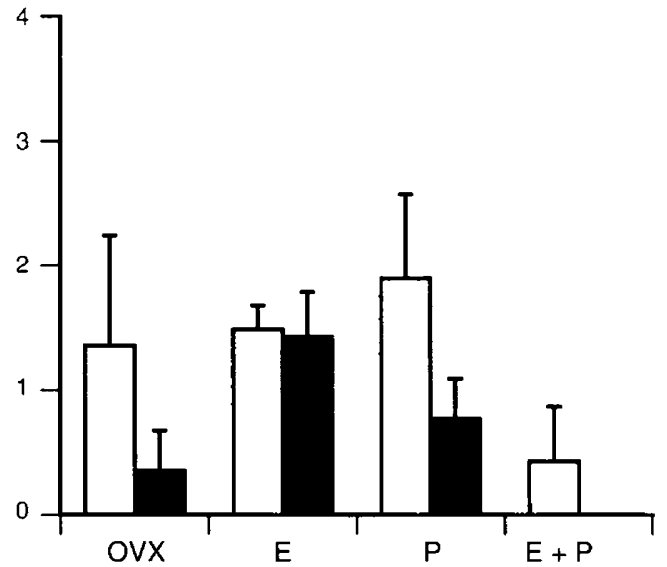

Fig. 7. Distribution and relative intensity of positive immunoreactivity for leukaemia inhibitory factor (LIF) in endometrial tissue of ovariectomized ewes and steroid treated ewes. (a) Luminal epithelium; (b) stroma, in the intercaruncular ( $\square$ ), and caruncular regions ( $\square$ ); (c) glandular epithelium, in outer $(\square)$ and deep glands ( $\square$ ). OVX: ovariectomized; E: oestradiol-treated; P: progesterone-treated; E + P: treated with oestradiol plus oestrogen.

in ovine endometrium on days 17 and 20 , and immunoreactive LIF was found on day 17 trophoblasts; this may have been bound to receptors or ovine trophoblasts may have been actively transcribing LIF.

In ovariectomized ewes treated with oestradiol, there was a reduction of immunoreactive LIF in the endometrium compared with control ovariectomized animals. Thus, oestradiol may regulate LIF expression in ovine endometrium, but it appears to be inhibitory. In the mouse uterus LIF is thought to be regulated by oestradiol (Bhatt et al., 1991; Yang et al., 1996) and there is a close link between the surge of oestradiol required for implantation and the burst of LIF expression (Bhatt et al., 1991), whereas in rabbits, LIF production appears to be controlled by progesterone (Yang et al., 1996). In sheep and rabbits, there is no association between oestradiol and implantation as in mice and this may explain why LIF expression and localization are not as precisely associated with implantation in sheep.

The cells in which the LIF transcript originates cannot be established immunohistochemically since the soluble protein may be endocytosed by reactive cells or bound to cell surface receptors. In the uterus of pregnant mice, mRNA transcripts encoding LIF detected by in situ hybridization were produced in the glandular epithelium and, to a lesser extent, in the luminal epithelium (Bhatt et al., 1991). In this study, LIF was detected immunohistochemically in stroma and epithelium, while separately cultured epithelial and stromal cells expressed mRNA encoding LIF. This finding indicates that both cell types can produce the LIF transcript in vitro in ewes. Epithelial cells are known to secrete proteins selectively either basally or apically (Cherny and Findlay, 1990). Therefore, if LIF is produced in the epithelium of the ovine uterus, it may be secreted apically into the lumen where it can interact with the embryo. Alternatively, LIF may also be secreted basally and this may account for the stromal immunostaining observed. In mice an alternative mRNA transcript encoding LIF has been reported that is associated with the extracellular matrix (ECM) in the stroma (Rathjen et al., 1990). This transcript is not conserved in other species such as humans, sheep and cows (Gough et al., 1992), but raises the possibility that immunoreactive LIF may be bound to ECM in the ovine endometrium and may require release for activity.

A number of studies have demonstrated that cytokines in vitro can elicit different biological effects depending on both the concentration and time of exposure. For example, LIF causes a dose-dependent increase in plasma protein expression of cultured H-35 rat hepatoma cells, but becomes inhibitory at concentrations greater than $1000 \mathrm{U} \mathrm{ml}^{-1}$ (Baumann et al., 1992). Furthermore, LIF at high concentrations regulates osteoblast proliferation in vitro, causing a transient stimulation of DNA synthesis within $24 \mathrm{~h}$. However, after $72 \mathrm{~h}$, LIF has inhibitory actions (Lowe et al., 1991). These results of in vitro studies indicate that the ligand of a pleiotropic cytokine does not have any intrinsic coded function and the response of a cell may depend on different transduction pathways coupled to the receptor. Thus, the endometrial LIF detected throughout the oestrous cycle, early pregnancy and in response to oestradiol and progesterone in ovariectomized animals may have either stimulatory or inhibitory or both effects on the endometrium or blastocyst at different stages.

In this study, LIF (transcript and protein) was detected in ovine endometrium throughout the oestrous cycle and early pregnancy, indicating that the expression of LIF in the endometrium of ewes is different from that in mice and humans. Whether LIF is required for blastocyst implantation in ewes is not known, but the expression of LIF throughout the 
extended developmental phase of the ovine blastocyst and its detection on day 17 in the trophoblast suggests that LIF may be involved in the development and implantation of the ovine blastocyst. Elucidation of the mechanisms involved in the regulation of LIF synthesis along with comparative studies of its actions await further investigation.

The authors are grateful to S. Riley and B. Doughton for assistance during animal surgery and to $S$. Garcia for northern analysis of cell preparations. D. Vogiagis was supported by the Victorian Education Foundation and L.A. Salamonsen by the NH and MRC of Australia. The AMRAD Corporation and AMRAD Pharmacia Biotech. generously provided the recombinant LIF and antibody, respectively.

\section{References}

Arici A, Engin O, Attar, E and Olive DL (1995) Modulation of leukemia inhibitory factor gene expression and protein biosynthesis in human endometrium Journal of Clinical Endocrinololgy and Metabolism 801908 1914

Baumann H, Marinkovic-Pajovic K, Won A, Jones VE, Campos SP, Jahreis GP and Morella KK (1992) The action of interleukin 6 and leukaemia inhibitory factor on liver cells. In Polyfunctional Cytokines: IL-6 and LIF pp 100-124 Eds GR Bock and K Widdows. John Wiley \& Sons Ltd, West Sussex

Bhatt H, Brunet LJ and Stewart CL (1991) Uterine expression of leukemia inhibitory factor coincides with the onset of blastocyst implantation Proceedings of the National Academy of Sciences USA $8811408-11412$

Bindon BM (1971) Systematic study of preimplantation stages of pregnancy in the sheep Australian Journal of Biological Science 24 131-147

Birkedal-Hansen $\mathrm{H}$, Moore WGI, Bodden MK, Windsor LJ, Birkedal-Hansen, B, De Carlo, A and Engler JA (1993) Matrix metalloproteinases: a review Critical Reviews of Oral Biology and Medicine 4 199-250

Boshier DP (1969) A histological and histochemical examination of implantation and early placentome formation in the sheep Journal of Reproduction and Fertility 19 51-61

Charnock-Jones DS, Sharkey AM, Fenwick P and Smith SK (1994) Leukemia inhibitory factor mRNA concentration peaks in human endometrium at the time of implantation and the blastocyst contains mRNA for the receptor at this time Journal of Reproduction and Fertility 101 421-426

Cherny RA and Findlay JK (1990) Isolation and culture of ovine endometrial epithelial and stromal cells: evidence of morphological and functional polarity Biology of Reproduction 43 241-251

Chomczynski P and Sacchi N (1987) Single-step method of RNA isolation by acid guanidinium thiocyanate-phenol-chloroform extraction Analytical Biochemistry 162 156-159

Cullinan EB, Abbondanzo SJ, Anderson PS, Pollard JW, Lessey BA and Stewart CL (1996) Leukemia inhibitory factor (LIF) and LIF receptor expression in human endometrium suggests a potential autocrine/paracrine function in regulating embryo implantation Proceedings of the National Academy of Sciences USA 93 3115-3120

Davis S, Aldrich TH, Stahl N, Pan L, Taga T, Kishomoto T, Ip NY and Yancopoulos GD (1993) LIFR $\beta$ and gp130 as heterodimerizing signal transducers of the tripartite CNTF receptor Science $2601805-1808$

Finn CA and McLaren A (1967) A study of the early stages of implantation Journal of Reproduction and Fertility $13259-267$

Fry RC, Batt PA, Fairclough RJ and Parr RA (1992) Human leukemia inhibitory factor improves the viability of cultured ovine embryos Biology of Reproduction 46 470-474

Gearing DP, Gough NM, King JA, Hilton DJ, Nicola NA, Simpson RJ, Nice EC, Kelso A and Metcalf D (1987) Molecular cloning and expression of cDNA encoding a murine myeloid leukaemia inhibitory factor (LIF) EMBO journal 6 3995-4002

Gearing DP, King JA, and Gough NM (1988) Complete sequence of murine myeloid leukaemia inhibitory factor (LIF) Nucleic Acid Research 169857

Gearing DP, Thut CJ, VandenBos T, Gimpel SD, Delaney PB, King J, Price V, Cosman D and Beckmann MP (1991) Leukemia inhibitory factor receptor is structurally related to the IL-6 signal transducer, gp 130 EMBO Journal 10 $2839-2848$
Gearing DP, Comeau MR, Friend DJ, Gimpel SD, Thut CJ, McGourty J, Brasher KK, King JA, Gillis S, Mosley J, Zieger SF and Cosman D (1992) The IL-6 signal transducer, $\mathrm{gp} 130$ : an oncostatin receptor and affinity converter for the LIF receptor Science 255 1434-1437

Gough NM, Willson TA, Stahl J and Brown MA (1992) Molecular biology of the leukemia inhibitory factor gene. In Polyfunctional Cytokines: IL-6 and LIF pp 24-46 Eds GR Bock and K Widdows. John Wiley \& Sons Ltd, West Sussex

Harvey MB, Leco KJ, Arcellana-Panililo MY, Zhang X, Edwards DR and Schultz GA (1995) Proteinase expression in early mouse embryos is regulated by leukaemia inhibitory factor Development 121 1005-1014

Hilton DJ, Nicola NA, and Metcalf D (1988) Purification of a murine leukaemia inhibitory factor from Krebs ascites conditioned cells Analytical Biochemistry $173 \quad 359-367$

Ip NY, Nye SH, Boulton TG, Davis S, Taga T, Li Y, Birren SJ, Yasukawa K, Kishimoto T, Anderson DJ, Stahl N and Yancopoulos GD (1992) CNTF and LIF act on neuronal cells via shared signaling pathways that involve the IL- 6 signal transducing receptor component gp130 Cell 69 1121-1132

Kojima K, Kanzaki H, Iwai M, Hatayama H, Fujimoto M, loue T, Horie K, Nakayama H, Fujita J and Mori T (1994) Expression of leukemia inhibitory factor in human endometrium and placenta Biology of Reproduction 50 $882-887$

Lavranos TC, Rathjen PD and Seamark RF (1995) Trophic effects of myeloid leukaemia inhibitory factor (LIF) on mouse embryos Journal of Reproduction and Fertility 105 331-338

Lowe C, Cornish J, Callon K, Martin TJ and Reid IR (1991) Regulation of osteoblast proliferation by leukemia inhibitory factor Journal of Bone and Mineral Research 6 1277-1283

Orsini MW, and McLaren A (1967) Loss of the zona pellucida in mice, and the effect of tubal ligation and ovariectomy Journal of Reproduction and Fertility 13 485-499

Rathjen DP, Toth S, Willis A, Heath JK and Smith AG (1990) Differentiation inhibiting activity is produced in matrix-associated and diffusable forms that are generated by alternate promoter usage Cell 62 1105-1114

Reynolds LP and Redmer DA (1992) Growth and microvascular development of the uterus during early pregnancy in ewes Biology of Reproduction 47 698-708

Robertson SA Lavranos TC and Seamark RF (1991) In vitro models of the maternal-fetal interface. In Molecular and Cellular Immunobiology of the Maternal-Fetal Interface pp 191-206 Eds TG Wegmann, TG Gill III and E Nisbet-Brown. Oxford University Press, New York

Rowson LEA and Moor RM (1966) The corpus luteum of the sheep: effect of the removal of embryos on luteal function Journal of Endocrinology 34 497-502

Salamonsen LA, O WS, Doughton B and Findlay JK (1985) The effects of estrogen and progesterone in vivo on protein synthesis and secretion by cultured epithelial cells from sheep endometrium Endocrinology 117 2148-2159

Salamonsen LA, Hampton AL, Clements JA and Findlay JK (1991) Regulation of gene expression and cellular localization of prostaglandin synthase by oestrogen and progesterone in the ovine uterus Journal of Reproduction and Fertility 92 393-406

Salamonsen LA, Nagase H and Woolley DE (1995) Matrix metalloproteinases and their tissue inhibitors at the ovine trophoblast-uterine interface Journal of Reproduction and Fertility Supplement 49 29-37

Salamonsen LA, Young R, Garcia S and Findlay JK (1997) Mitogenic actions of endothelin and other growth factors in ovine endometrium Journal of Endocrinology 152 283-290

Smith AG, Heath JK, Donaldson DD, Wong GG, Moreau J, Stahl M and Rogers D (1988) Inhibition of pluripotential embryonic stem cell differentiation by purified polypeptides Nature $336688-690$

Stewart CL, Kaspar P, Brunet LJ, Bhatt H, Gadi I, Kontgen F and Abbondanzo ST (1992) Blastocyst implantation depends on maternal expression of leukaemia inhibitory factor Nature 359 76-79

Taga T and Kishimoto T (1992) Cytokine receptors and signal transduction FASEB Journal 6 3387-3396

Tomida M, Yamamoto-Yamaguchi $Y$ and Hozumi M (1984) Purification of a factor inducing differentiation of mouse myeloid leukaemic M1 cells from conditional medium of mouse fibroblast L929 cells Journal of Biological Chemistry $25910978-10982$

Vogiagis D, Marsh M M, Fry RC and Salamonsen LA (1996) Leukaemia inhibitory factor in human endometrium throughout the menstrual cycle Journal of Endocrinology 148 95-102 
Ware CB, Horowitz MC, Renshaw BR, Hunt JS, Liggitt D, Koblar SA, Gliniak BC, McKenna HJ, Papaynnopoulou T, Thoma B, Cheng L, Donovan PJ, Peschon JJ, Bartlett PF, Willis CR, Wright BD, Carpenter MK, Davidson BL and Gearing DP (1995) Targeted disruption of the low-affinity leukemia inhibitory factor receptor gene causes placental, skeletal, neural and metabolic defects and results in perinatal death Development 121 1283-1299

Williams RL, Hilton DJ, Pease S, Willson TA, Stewart CL, Gearing DP, Wagner EF, Metcalf D, Nicola NA and Gough NM (1988) Myeloid leukemia inhibitory factor maintains the developmental potential of embryonic stem cells Nature $336 \quad 684-687$

Willson TA, Metcalf D and Gough NM (1992) Cross-species comparison of the sequence of the leukemia inhibitory factor gene and its protein European Journal of Biochemistry 204 21-30

Woessner JF, Jr (1991) Matrix metalloproteinases and their inhibitors in connective tissue remodeling FASEB Journal 5 2145-2154

Wooding FBP and Flint APF (1994) Placentation. In Marshall's Physiology of Reproduction 4th edn Pregnancy and Lactation Part 1. Ovulation and Early Pregnancy pp 235-429 Ed. GE Lamming. Chapman \& Hall, London
Yang ZM, Le SP, Chen DB and Harper MKJ (1994) Temporal and spatial expresssion of leukemia inhibitory factor in rabbit uterus during early pregnancy Molecular Reproduction and Development 38 148-152

Yang ZM, Le SP, Chen DB, Cota J, Siero V, Yasukawa K and Harper MKJ (1995) Leukemia inhibitory factor. LiF receptor and gp130 in the mouse uterus during early pregnancy Molecular Reproduction and Development $\mathbf{4 2}$ 407-414

Yang ZM, Chen DB, Le SP and Harper MKJ (1996) Differential hormonal regulation of leukemia inhibitory factor (LIF) in rabbit and mouse uterus Molecular Reproduction and Development 43 470-476

Yoshida K, Taga T, Saito M, Suematsu S, Kumanogoh A, Tanaka T, Fujiwara H,Hirata M, Yamagami T, Nakahata T, Hirabayashi T, Yoneda Y, Tanaka K, Wang W-Z, Mori C, Shiota K, Yoshida N and Kishimoto T (1996) Targeted disruption of gp130, a common signal transducer for the interleukin 6 family of cytokines, leads to myocardial and haematological disorders Proceedings of the National Academy of Sciences USA 93 407-411 